\title{
Hematopoietic development of embryonic stem cells in vitro: cytokine and receptor gene expression
}

\author{
Regina M. Schmitt, ${ }^{1}$ Eddy Bruyns, ${ }^{1}$ and H. Ralph Snodgrass ${ }^{2}$ \\ Lineberger Comprehensive Cancer Center, University of North Carolina, Chapel Hill, North Carolina 27599 USA
}

\begin{abstract}
A novel system to study early hematopoietic development is described. This report documents the in vitro capacity of murine embryonic stem (ES) cells to differentiate into hematopoietic precursors of most, if not all, of the colony-forming cells found in normal bone marrow. This system is used to correlate the genetic expression of cytokines, their receptors, the $\beta$-globins, and the hematopoietic cell surface markers throughout the time course of ES cell differentiation with the hematopoietic development that occurs in these cultures. Our results indicate that there is a strong transcriptional activation, in a well-defined temporal order, of most of these genes including erythropoietin (Epo), CSF-1, IL-4, IL-6, $\beta$-globins, as well as the receptors for Epo, CSF-1, and IL-4. IL-3 and GM-CSF were not expressed during the first 24 days of ES cell differentiation. In contrast, the Steel (SI) factor (SLF) was expressed early and underwent substantial up-regulation during this differentiation, and its receptor, c-kit, was expressed relatively constantly throughout the culture period. Our results are consistent with the conclusion that SLF, Epo, IL-4, and IL-6 are important during the early stages of ES cell differentiation and hematopoietic development. Furthermore, these results argue strongly that IL-3 and GM-CSF are not critical to early hematopoiesis. This system offers a unique in vitro model for studying hematopoietic development at the earliest possible stages.
\end{abstract}

[Key Words: Hematopoiesis; stem cells; CSF; interleukins; ES cells; development]

Received December 14, 1990; revised version accepted March 1, 1991.

Most mature blood cells are short lived and must be replaced continuously throughout adult life from a selfrenewing population of pluripotent hematopoietic stem cells located mainly in the bone marrow. These stem cells produce progenitor cells committed to one of the hematopoietic lineages (Micklem and Ogden 1976; Abramson et al. 1977), including erythrocytes, megakaryocytes, granulocytes, monocytes, and lymphocytes. The first fetal hematopoietic precursors appear in the yolk sac (Russell 1979). As development proceeds the major site of hematopoiesis shifts to the fetal liver and subsequently to the bone marrow. In contrast to the large body of data available on the control of adult hematopoiesis, very little is known about the induction and control of fetal hematopoietic development or about what growth factors are involved during this stage of development. This is caused in part by the lack of a suitable in vitro experimental system.

Many cytokines have been shown to be important to hematopoietic development, such as erythropoietin (Epo) (Iscove and Sieber 1975), granulocyte colony-stimulating factor (G-CSF) (Nicola et al. 1983), macrophageCSF (M-CSF or CSF-1) (Stanley and Heard 1977), granulocyte/macrophage-CSF (GM-CSF) (Metcalf et al. 1980),

\footnotetext{
${ }^{1}$ These authors contributed equally to this project.

${ }^{2}$ Corresponding author.
}

interleukin 1 (IL-1) (Mochizuki et al. 1987), IL-3 (Iscove and Roitsch 1985), IL-4 (Paul and Ohara 1987), and IL-6 (Wong et al. 1988). These factors range from being lineage specific, such as Epo and CSF-1, to acting on multiple lineages, such as IL-3 and GM-CSF. The recently described Steel factor (SLF) (Anderson et al. 1990; Zsebo et al. 1990) and its receptor, c-kit (Chabot et al. 1988; Geissler et al. 1988), are critical to hematopoietic, germ cell, and melanocyte development, although their precise functions during development are not clear (Russell 1979; Silvers 1979).

Embryonic stem (ES) cells are totipotent cells that are derived from the inner cell mass of mouse blastocysts and can be kept apparently indefinitely in culture (Evans and Kaufman 1981; Martin 1981; Suda et al. 1987). If injected into mouse blastocysts these cells contribute to all tissues, including the germ cells, of the developing animal (Bradley et al. 1984). ES cells are kept undifferentiated by coculture with feeder cells (Martin and Evans $1975 \mathrm{a}, \mathrm{b}$ ) or by addition of leukemia inhibitory factor (LIF), which inhibits their differentiation (Williams et al. 1988). If LIF is withdrawn, ES cells undergo differentiation culminating in complex cystic embryoid bodies with endoderm, mesoderm, and ectoderm resembling the 6- to 8-day egg cylinder stage in normal embryonic development. These embryoid bodies contain two of the major products of the visceral yolk sac, $\alpha$-fetoprotein and 
transferrin, and some develop visible blood islands (Doetschman et al. 1985). Little more is known about the hematopoietic development that occurs in this system. Identifying the regulatory controls of this early hematopoietic development would contribute greatly to our overall understanding of the biology of the hematopoietic system.

This communication reports the temporal hematopoietic development of ES cells as analyzed by colony formation in methylcellulose and by the expression of genes known to be influential during hematopoietic development. Neither IL-3 nor GM-CSF, two factors that have effects on immature hematopoietic cells, were expressed during ES cell differentiation, although the primitive precursor of multilineage colonies was produced. This led to the hypothesis that IL-3 and GM-CSF were not required and prompted us to analyze the expression of additional factors, including IL-4, IL-6, and SLF, which have been shown to enhance hematopoiesis (Wong et al. 1988; Rennick et al. 1989; Anderson et al. 1990; Zsebo et al. 1990). In addition to yielding new information on hematopoietic development, these studies demonstrate that this novel in vitro system offers a unique opportunity to study the control of hematopoietic development at the earliest stages when hematopoietic cells are differentiating from their nonhematopoietic precursors.

\section{Results}

ES cell system

Each of three independent murine ES cell lines that we have studied is capable of differentiating into hematopoietic cells. In this communication we report the results using the 1E6/2 ES cell line. ES cells are induced to differentiate by the combined effects of removing the differentiation inhibiting factor (LIF) and maintaining the ES cells in suspension cultures. These effects together with critical cell-cell interactions induce the formation of complex embryoid bodies that develop blood islands. Blood-island formation becomes obvious starting around day 8 of differentiation and is correlated with the development of microscopically distinct clusters of uniformly round cells within the developing cysts. Kemler and colleagues reported that human cord serum (HCS) dramatically improves the blood island development in ES cell differentiation cultures (Doetschman et al. 1985). We have confirmed those results and have observed that HCS also has a dramatic promoting effect on the development of in vitro colony-forming cells (see below). In optimal cultures, $5-30 \%$ of the cysts have visible blood islands at any one time, although most if not all cysts will eventually develop them (data not shown).

\section{In vitro development of hematopoietic colonies from ES cells}

To investigate their hematopoietic potential, single cell suspensions were prepared from ES cell differentiation cultures at various times and evaluated by methylcellulose colony assays. These studies indicated that differentiating ES cells are able to produce most if not all of the colony-forming cells found in normal bone marrow. Figure 1 is an example of a May-Grünwald-Giemsa stain of a smear from a mixed colony from ES cells that were differentiated for 16 days in vitro. This colony was derived from a multipotential precursor that gave rise to erythrocytes, macrophages, neutrophils, and cells with basophilic granules that, because of the culture conditions, are probably mast cells. Other hematopoietic colonies were produced in ES cell differentiation cultures, including erythroid, macrophage, neutrophil, mast cell, as well as colonies containing granulocytes and macrophages. In addition to the hematopoietic colonies, nonhematopoietic colonies were detected but not identified.

To study the time course and extent of hematopoietic development, we quantitated the colony-forming cells that developed during ES cell differentiation from 0 to 28 days. Starting at day 12 it was possible to separate the macroscopically visible hollow cysts from the nonhollow structures. In general, $>90 \%$ of the hematopoietic colony-forming precursors were associated with the large cysts; therefore, only the colony data from the cysts are shown from day 12 on. For the gene expression stud-

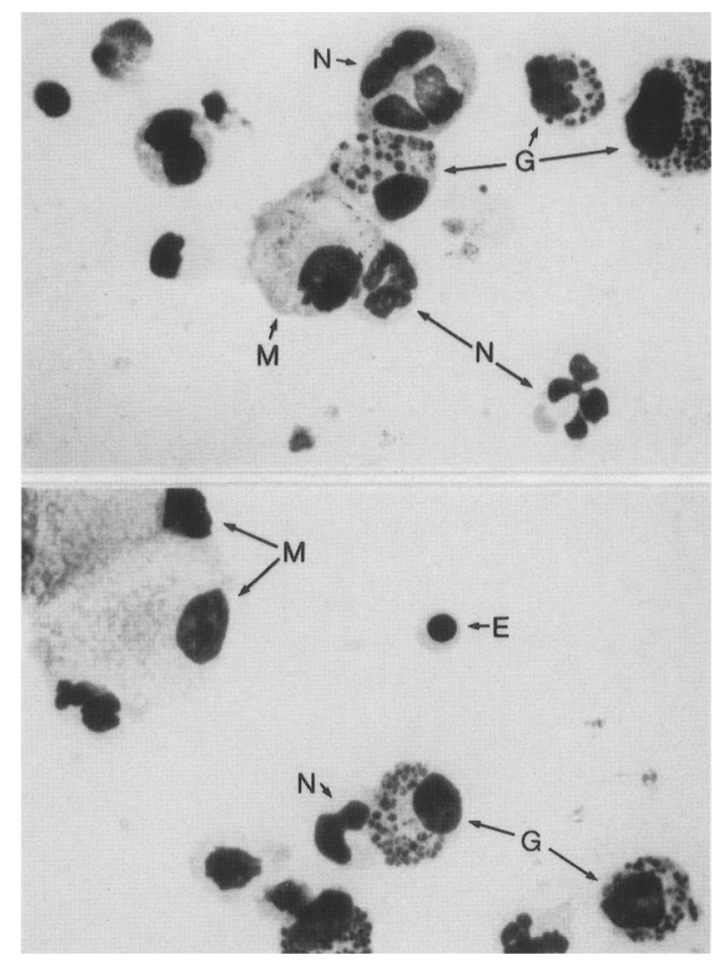

Figure 1. Cytological analysis of an ES cell-derived mixed colony. A smear was prepared from a methylcellulose-derived mixed colony that developed from day-16 differentiated ES cells. The slide was air-dried and stained with May-GrünwaldGiemsa by standard techniques. (E) Erythroid precursor; (M) macrophage; (N) neutrophil; (G) cells with basophilic granules which, because of the culture conditions, are most probably mast cells. 
ies, data from both the cysts and the noncysts are presented. Figure 2 illustrates the development of hematopoietic colony-forming cells from differentiating ES cells in three separate time course experiments from day $2-28$. We have not seen hematopoietic colonies from ES cells differentiated for $<2$ days. Colony data from day 12 and day 16 of differentiation from two additional experiments are also included. For these figures we have combined the data for all of the various myeloid colonies, that is, pure macrophage, pure neutrophil, pure mast cell, and the colonies derived from the more immature precursors containing combinations of these cells under the category of granulocyte/macrophage. Although there was variation in the onset, extent, and duration, significant hematopoietic development occurred in all five experiments.

Our data indicate that there are significant differences between ES cell and bone marrow-derived colony-forming units (CFU). Based on a percentage of total hematopoietic colonies from six experiments, ES cell differentiation cultures yielded $31 \pm 12 \%$. mixed, $48 \pm 12 \%$ erythroid, $8 \pm 8 \%$ single lineage myeloid (macrophage, neutrophil, or mast cell), and $17 \pm 4 \%$ GM colonies (Fig. 2 and data not shown). This compares with $1.0 \pm 1 \%$ mixed, $1.7 \pm 1 \%$ erythroid, $69 \pm 4 \%$ single lineage myeloid (macrophage, neutrophil, or mast cell), and $28 \pm 3 \%$ GM colonies from C57BL/6 normal bone

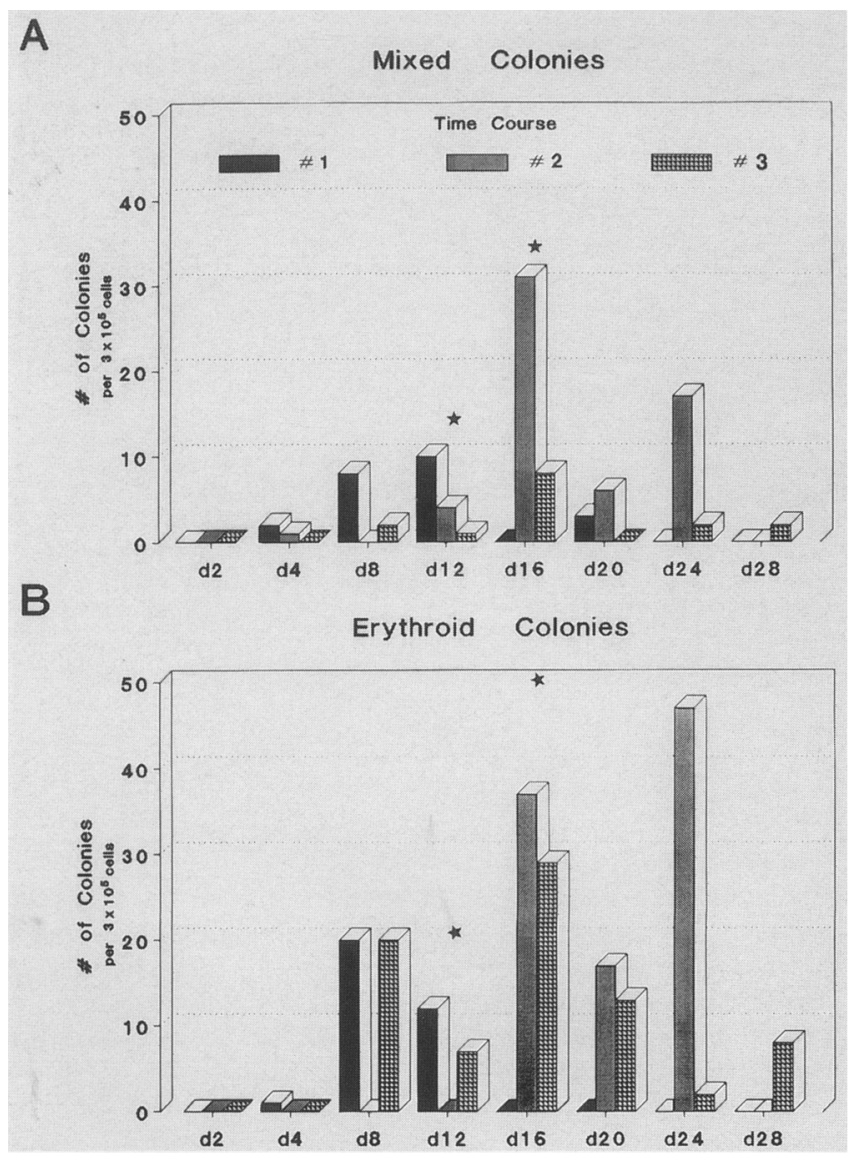

marrow in 10 experiments (data not shown). This represents a dramatic increase in the frequency of the primitive mixed and erythroid colonies, and a decrease in the mature single lineage myeloid colonies in differentiating ES cell cultures compared with adult bone marrow.

\section{Hematopoietic cell-surface marker expression}

The frequency of cells expressing hematopoietic surface markers was evaluated by flow cytometry. CD45 (Ly-5) is a surface marker that is expressed on almost all hematopoietic cells (Miller et al. 1985; Thomas 1989), whereas Thy- 1 is expressed on T cells, immature hematopoietic precursors, and some neural cells (Reif and Allen 1964; Berman and Basch 1985). Ly-6A (Sca-1) is expressed on lymphocytes, bone marrow cells, neutrophils, macrophages, and hematopoietic stem cells (Shevach and Korty 1989; van de Rijn et al. 1989). Table 1 lists the results of fluorescence-activated cell sorting (FACS) analyses of differentiated ES cells. Of the cells from day $16-24$ cysts, $2 \%$ were $\mathrm{CD}_{4} 5^{+}, 1 \%$ were Thy $-1^{+}$, and $0.8 \%$ expressed Ly-6A. There was no expression above background of the neutrophil marker RB6-8C5 (Coffman 1982), the macrophage marker MAC1 (Springer et al. 1978), or the antigen that is found on B cells and hematopoietic stem cells, AA4.1 (Jordan et al. 1990) (Table 1). There was no consistent significant ex-

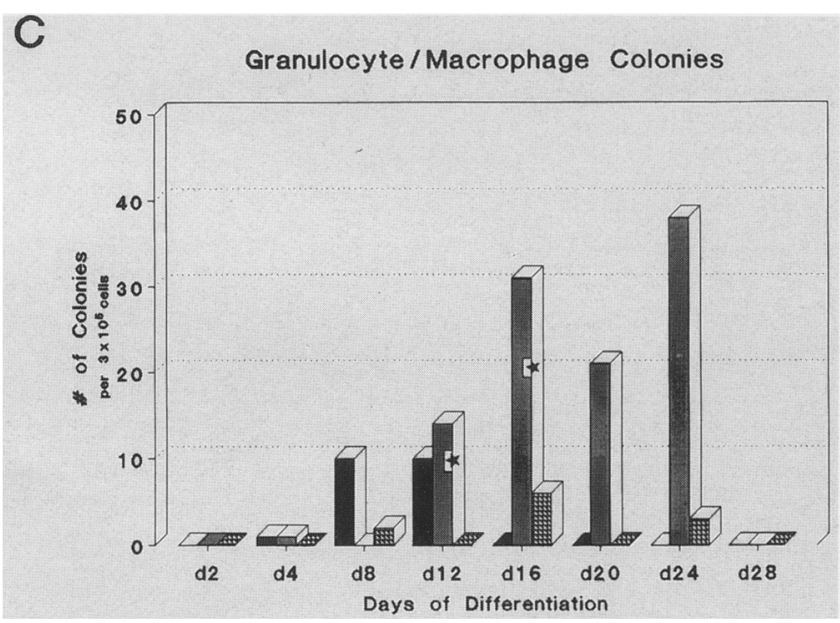

Figure 2. Hematopoietic colony formation from differentiated ES cells. ES cells were taken at the days of differentiation culture as indicated, and single-cell suspensions were assayed in methylcellulose cultures as described in Materials and methods. Hematopoietic colonies counted on day 8 (d8) of the methylcellulose cultures are shown. From day 12 of ES cell differentiation on, only the colony data originating from the macroscopically visible hollow cysts are presented. Three separate time courses (solid box, time course 1; shaded box, time course 2; checked box, time course 3 ) and single time points from two additional experiments $\left({ }^{*}\right)$ are shown. $(A)$ Mixed colonies; $(B)$ erythroid colonies, i.e., erythroid burst-forming units $(B F U-E) ;(C)$ granulocytic-monocytic colonies (including duallineage GM-type, as well as pure granulocytic and monocytic colonies) formed by the differentiating ES cells. 
Table 1. Hematopoietic marker analysis of differentiated ES cells

\begin{tabular}{lllrl}
\hline & \multicolumn{4}{c}{ Percent positive cells $^{\mathrm{a}}$} \\
\cline { 2 - 5 } $\begin{array}{l}\text { Marker } \\
\text { (antibody) }^{\mathrm{b}}\end{array}$ & $\begin{array}{l}\text { undifferentiated } \\
\text { ES cells }\end{array}$ & $\begin{array}{l}\text { differentiated } \\
\text { ES cells }\end{array}$ & spleen & bone \\
marrow \\
\hline CD45 (Ly-5) & - & $1.8^{\mathrm{c}}$ & 100 & nd \\
Thy-1 & - & 1.0 & 40 & nd \\
Ly-6A & - & 0.8 & 72 & 6 \\
B220 & - & - & 43 & nd \\
RB6-8C5 & - & - & nd & 67 \\
MAC-1 & - & - & nd & 65 \\
AA4.1 & - & - & nd & 19 \\
\hline
\end{tabular}

andifferentiated and differentiated ES cells from day 16-25 of differentiation were trypsinized to give single cell suspensions, stained, and analyzed as described in Materials and methods. The results represent the data from one to three experiments. $(-)<0.5 \%$; (nd) not done.

bee Materials and methods.

${ }^{\mathrm{c}}$ Average of three experiments from days 16-25.

pression of the B-cell lineage marker B220 /Coffman and Weissman 1981), but in some experiments very small $(0.3-0.5 \%)$ differences from the background were detected, which were not observed with other negative antibodies.

\section{Gene expression during ES cell differentiation}

To understand better the growth control of hematopoietic cells during the in vitro differentiation of ES cells, we investigated the expression of a number of genes known to be involved in adult hematopoiesis. The time point at which a particular factor and its receptor undergoes significant expression will suggest when that factor begins to play a role in the differentiation process. Likewise, the lack of expression of a particular cytokine and its receptor would be strong evidence that the factor is not critical for development at that stage. Expression studies were accomplished by using reverse transcriptase-dependent polymerase chain reaction (RTPCR) (Ohara et al. 1989) to determine the relative steadystate mRNA levels throughout the developmental time course. The analysis of gene expression was performed on time courses 1 and 2, as well as selected time points from other experiments. With exception to the exact day of onset of expression, all of the results were comparable; therefore, only the data from time course 2 are presented in Figures 3-7. We included several normal tissues and cell lines as controls, including STO cells that are used many times to maintain undifferentiated ES cells (Martin and Evans 1975a). Except during the initial isolation, all of our ES cell cultures were maintained without feeder cells of any kind. As discussed in Materials and methods, all of our experiments were standardized by $\beta$-actin amplification (Fig. 3). All of the results to be described below are summarized in Table 2, which lists these genes according to their temporal order of expression.
The expression of $\beta$-globin is obvious in the developing cysts by the visual appearance of hemoglobin. This expression was confirmed by analyses of $\beta$-globin RNA levels. Figure 4 shows the result of the RT-PCR amplification of the fetal $y$ and the adult $b 1 \beta$-globin cDNAs during 24 days of differentiation. Neither of these genes is expressed in undifferentiated ES cells, and both undergo a strong induction during differentiation. The expression of fetal globin predominates from the preculture stage through day 8 , and then both fetal and adult genes are expressed at significant levels throughout the rest of the time course (Fig. 4). This contrasts to the fact that mature erythroid methylcellulose colonies derived from day 16 cysts expressed almost exclusively adult globin (data not shown). As observed with several other genes, the globin genes are predominantly expressed in the large developing cysts.

It is obvious by the colony assays that substantial hematopoietic development is occurring during the differentiation of ES cells. Another indication of hematopoietic development is the appearance of CD45 (Ly-5), which is a surface marker found on most hematopoietic cells. Primers designed to amplify the 3 ' portion of the CD45 gene, which is present in all known forms of the molecule (Thomas 1989), were used to show that this gene

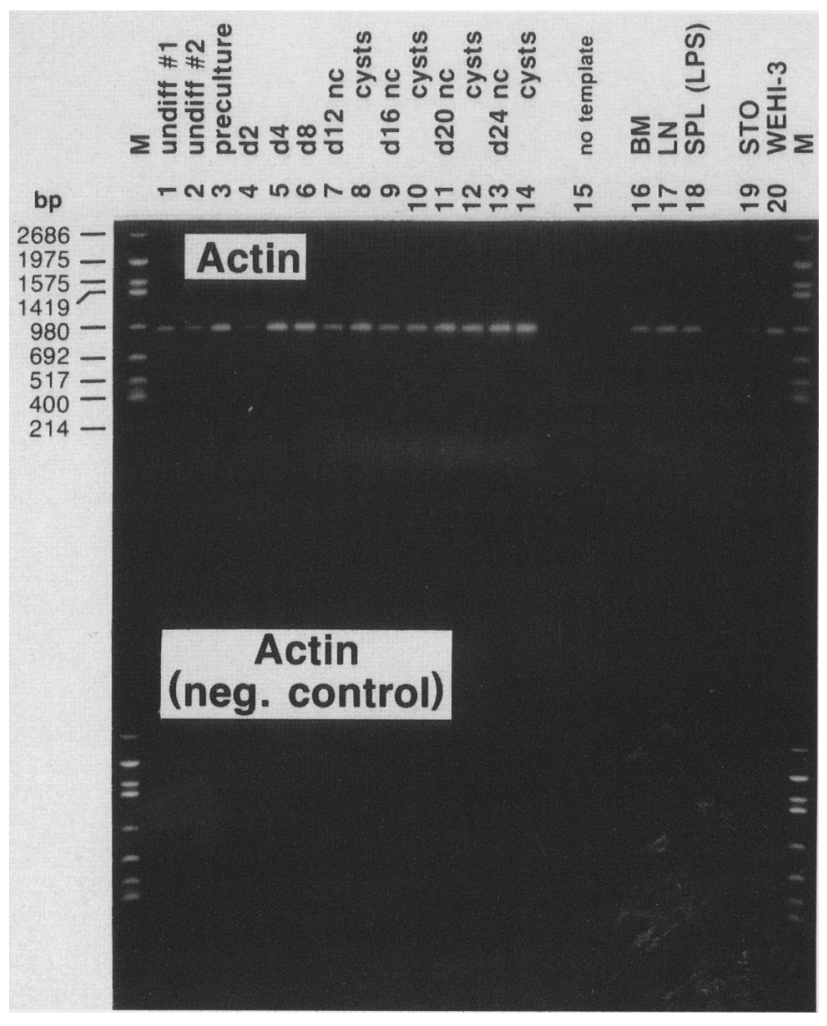

Figure 3. Expression of the $\beta$-actin gene during ES cell differentiation analyzed by RT-PCR. The PCR with primers specific for $\beta$-actin was performed for only 25 cycles to stay in the linear range of the amplification reaction. The faint band in day 12 noncysts and day 20 cysts in the reverse transcriptase minus (neg. control) control is derived from contaminating genomic DNA. 
Table 2. Expression of genes related to hematopoiesis during ES cell differentiation ${ }^{\mathrm{a}}$

\begin{tabular}{|c|c|c|c|c|c|c|c|c|c|}
\hline \multirow[b]{2}{*}{ Gene } & \multicolumn{9}{|c|}{ Differentiated ES cells ${ }^{\mathrm{b}}$} \\
\hline & undiff & pre & $\mathrm{d} 2$ & $\mathrm{~d} 4$ & $\mathrm{~d} 8$ & $\mathrm{~d} 12 \mathrm{c}$ & $\mathrm{d} 16 \mathrm{c}$ & $\mathrm{d} 20 \mathrm{c}$ & $\mathrm{d} 24 \mathrm{c}$ \\
\hline c-kit & $+^{c}$ & ++ & ++ & ++ & ++ & ++ & ++ & ++ & ++ \\
\hline SLF & + & + & + & + & + & ++ & ++ & +++ & $++t$ \\
\hline Thy-1 & + & ++ & ++ & $+t$ & ++ & ++ & ++ & +++ & +++ \\
\hline Epo receptor & $-{ }^{d}$ & ++ & + & + & ++ & ++ & ++ & ++ & ++ \\
\hline Epo & $-d$ & + & ++ & + & + & + & + & ++ & ++ \\
\hline IL-4 receptor & $-{ }^{d}$ & + & + & + & + & ++ & ++ & $+t+$ & +++ \\
\hline B-Globin (fetal) & - & + & ++ & + & + & +++ & +++ & +++ & +++ \\
\hline CSF-1 & - & ++ & - & + & ++ & ++ & ++ & +++ & +++ \\
\hline IL-6 & - & ++ & - & - & - & ++ & + & ++ & +++ \\
\hline IL -4 & - & - & + & - & - & + & +++ & +++ & + \\
\hline$\beta$-Globin (adult) & - & - & \pm & - & \pm & ++ & +++ & +++ & +++ \\
\hline IL -3 receptor & - & - & - & + & + & ++ & ++ & +++ & +++ \\
\hline CSF-1 receptor & - & - & - & - & \pm & ++ & ++ & +++ & +++ \\
\hline IL-1 -receptor & - & - & - & - & - & ++ & ++ & +++ & +++ \\
\hline CD45 (Ly-5) & - & - & - & - & - & + & + & ++ & ++ \\
\hline G-CSF receptor & - & - & - & - & - & ++ & ++ & ++ & ++ \\
\hline $\mathrm{IL}-1 \beta$ & - & - & - & - & - & + & ++ & $++t$ & +++ \\
\hline G-CSF & - & + & - & - & - & - & - & $-\mathrm{e}$ & ++ \\
\hline IL-1 $\alpha$ & - & - & - & - & - & - & - & + & $-{ }^{e}$ \\
\hline GM-CSF & - & - & - & - & - & - & - & - & - \\
\hline IL-3 & - & - & - & - & - & - & - & - & - \\
\hline
\end{tabular}

aSummary of the PCR data taken from Figs. 4-7 listed in the order of temporal appearance.

b(undiff) Undifferentiated ES cell colonies picked by micromanipulation; (pre) preculture as described in Materials and methods; (c) from day 12 on only the results from the cyst fraction are given. Note that there are differences between cysts and noncysts in the expression of some genes that are not reflected in this table (Figs. 4-6).

'This is to indicate a relative level of expression for a given gene during the time course of the experiment. It must be stressed that it is not valid to use this data to compare the levels of expression of one gene with another; therefore, no effort was made to do so. ${ }^{d}$ In some, but not all, preparations of undifferentiated ES cells a weak expression of these genes was seen at high numbers of amplification cycles.

'There was a signal in the noncyst fraction from this time point (Figs. 5 and 6 ).

becomes transcriptionally active around day 12 , and increases its expression up to day 24 of differentiation (Fig. 4). Although the level of CD45 expression at the termination of the experiment was significant, it was still well below that of the hematopoietic tissue controls, such as bone marrow, lymph node, and lipopolysaccharide (LPS)activated spleen cells, which all have greater than $90 \%$ CD $45^{+}$cells. The level of CD45 RNA in differentiating ES cells is concordant with the fact that only $2 \%$ of day 16 differentiated cells express CD45 surface molecules (Table 1).

Thy-1 was expressed at significant levels in undifferentiated ES cell samples (this is not readily apparent in the reproduction of Fig. 4). At later stages of ES cell differentiation, the level of Thy-1 mRNA expression approaches that seen in normal tissues, such as lymph node, which has $\sim 60 \%$ Thy- $1^{+}$cells. This was unexpected as we have never observed $>1 \%$ of the differentiated ES cells to be Thy-1 ${ }^{+}$(Table 1). The explanation of this seemingly high-level "nonproductive" transcription of the thy-1 gene is not known.

\section{Expression of CSFs and their receptors}

Determining the expression patterns during ES cell differentiation of the cytokines and their receptors, which are known to be important to adult hematopoiesis, is fundamental to our understanding of the induction and control of hematopoietic development. Figure 5 shows the RT-PCR analysis of GM-CSF, Epo, CSF-1, G-CSF, and their receptors (except for the receptor for GM-CSF, which has not yet been cloned in the mouse). With two exceptions, none of these molecules are expressed in undifferentiated ES cells. Although not obvious in Figure 5, some experiments suggest that Epo and its receptor are weakly transcribed in some undifferentiated samples. It is likely that this low-level sporadic expression in undifferentiated cells of these "early" genes (Table 2) is a result of the preparation containing small amounts of differentiated cells. The major transcriptional activation of these genes occurs during the preculture stage, which demonstrates that during this period, in addition to expanding, the ES cell colony begins to differentiate. The origin of the two hybridizing reverse transcriptase-dependent Epo bands falling between the genomic and cDNA bands on day 20-24 cysts (Fig. 5) is unknown, but they may be related to splicing intermediates that are occasionally detected in these PCR analyses. The same may be the case with the Epo receptor, in which the PCR product appears as a double band of which the lower is the expected size of mature cDNA. CSF-1 is also induced during the preculture stage, but cannot be detected at 


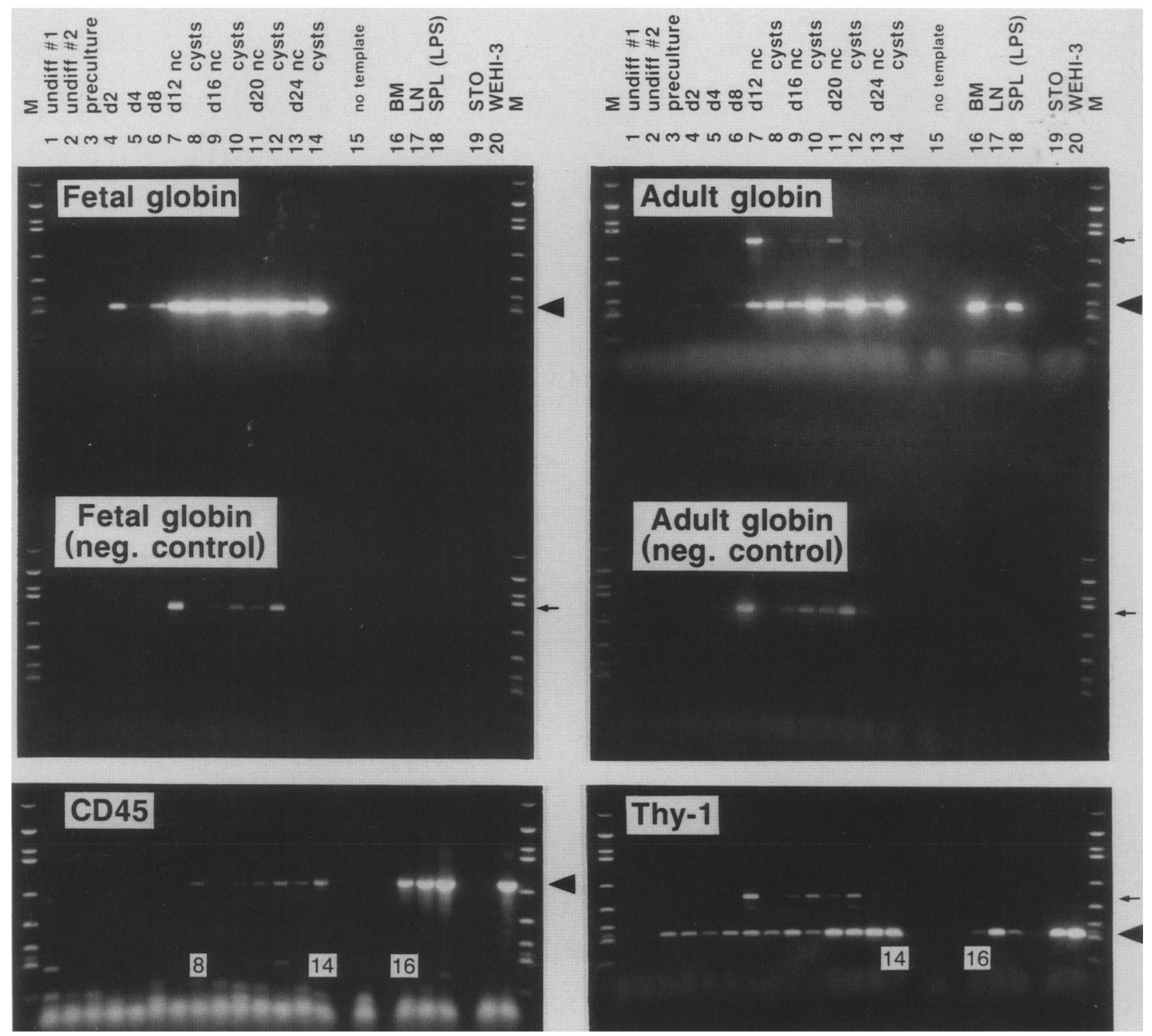

Figure 4. Expression of globin and cell-surface marker genes during ES cell differentiation analyzed by RT-PCR. Ethidium bromide stain of the amplification products of fetal $\beta$-globin $(y)$, adult $\beta$-globin $(b 1), C D 45$, and Thy- 1 . All amplifications were performed for 35 cycles with the exception of CD45, which was carried out for 45 cycles. The distribution of the samples on the gels is the same for every RT-PCR presented in this report and is always shown for the upper row of gels. Sample numbers are indicated in the lower row. The specific gene that was detected in any given PCR is denoted for every gel. Here, we show two sets of controls not containing reverse transcriptase during the first-strand synthesis (neg. control) for fetal $\beta$-globin and adult $\beta$-globin. These negative control examples are characteristic for all of the other amplifications. It is obvious that the negative control amplifies only the band derived from the genomic DNA (arrow), whereas the cDNA band (arrowhead) is absent in this control. For our other results we present only the reverse transcriptase positive samples.

day 2 , and then reappears on day 4 . We do not know whether this phenomenon, which was also observed with other genes, is due to natural regulation or whether it is attributable to the temporary shock of transferring the cells from the preculture to the differentiation culture, but it is interesting that so far this phenomenon has only been observed with factors. The nature of the 450bp band amplified in the CSF-1 PCR from STO cells is not known, but it hybridizes under stringent conditions to the CSF-1 probe (data not shown). The CSF-1 receptor is expressed weakly at day 8 and strongly from day 12 on. There was no evidence of GM-CSF expression in the differentiated ES cells even after hybridization (Fig. 5). In contrast, GM-CSF mRNA was readily detected in the LPS-stimulated spleen and STO cell controls. The sensitivity of our PCR reactions is such /see Materials and methods) that we can conclude that there is no functionally significant expression of GM-CSF in differentiating ES cell cultures.

Although there was a transient low-level expression of 

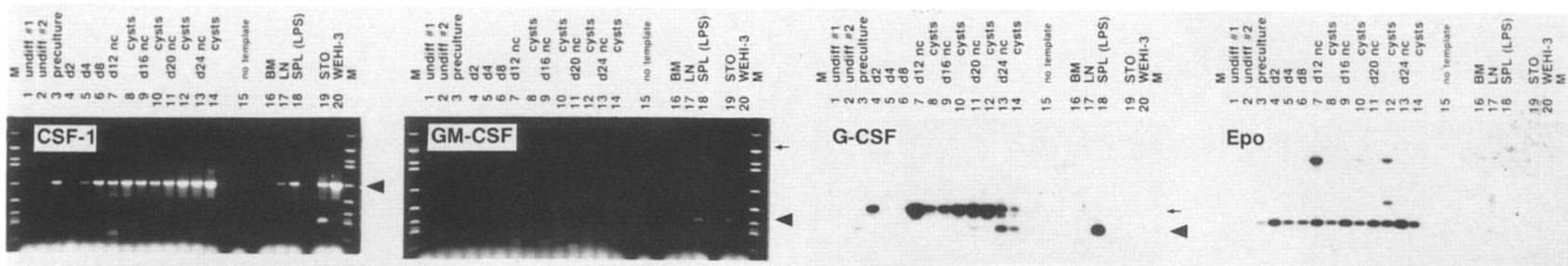

G-CSF

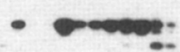

Epo
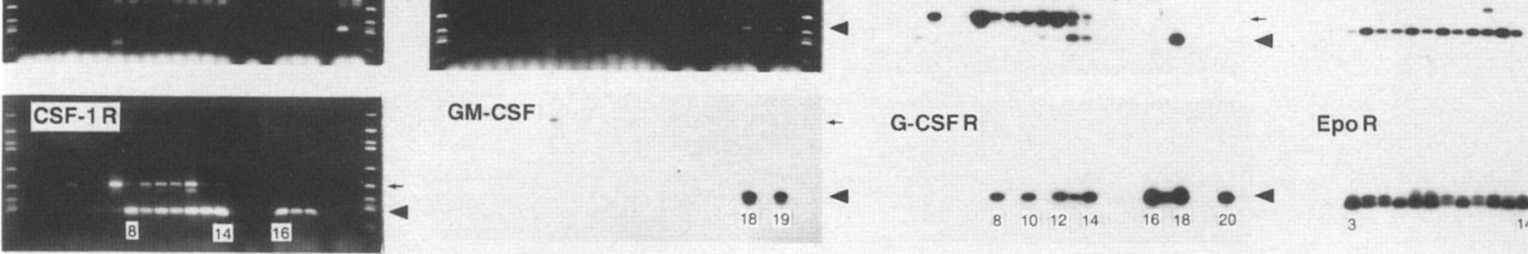

GM-CSF

G-CSF R

EpoR
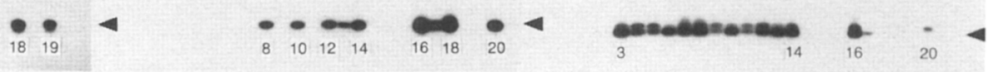

Figure 5. Expression of genes coding for CSFs and their receptors during ES cell differentiation analyzed by RT-PCR. Ethidium bromide stain or hybridization of the amplification products of CSF-1, CSF-1 receptor, GM-CSF, G-CSF, G-CSF receptor, Epo, and Epo receptor. All amplifications were performed for 50 cycles with the exception of CSF-1 and Epo, which were carried out for 35 and 40 cycles, respectively. The arrow indicates the genomic DNA band; the arrowhead indicates the cDNA band.

G-CSF in the preculture stage, the first significant expression of mature fully processed mRNA was only detected on day 20 , whereas transcription of its receptor was detected as early as day 12 (Fig. 5). The G-CSF RTPCR shows three bands, all of which are reverse transcriptase dependent and hybridize under stringent conditions to a G-CSF-specific oligonucleotide: (1) the fully processed cDNA band of 427 bp expressed at high levels only at day 24 of ES cell development and in LPS-activated spleen cells; (2) a band that is the same size as the primary genomic transcript expressed throughout most of the time course; and $|3|$ a band of $\sim 650 \mathrm{bp}$ that is slightly smaller than the primary transcript and may be a splicing intermediate. These three bands were consistently observed with four different G-CSF-specific primer pairs (data not shown). The fact that mature mRNA is not seen in every sample that contains the primary genomic transcript and that the presumed splicing intermediate is only observed in samples that have the mature transcript suggests that the splicing of the G-CSF primary transcript is developmentally well regulated.

The transcription of the G-CSF receptor demonstrates a strong cyst to noncyst difference (Fig. 5). The majority of G-CSF receptor mRNA expression occurs in the cyst fraction, whereas it is not detected in the noncysts until day 24 where it is expressed at comparatively low levels. This selective expression is similar to our findings presented above that the cysts contain the vast majority of colony-forming cells. Although not as obvious in this particular experiment, the CD 45 , IL-1 $\beta$, and globin genes exhibit a similar preferential expression in cysts versus noncysts (Figs. 4 and 6 and E. Bruyns, unpubl.). The opposite is observed with Epo, IL-1 $\alpha$, IL-6, and G-CSF, which are expressed preferentially in the noncyst fractions (Figs. 5 and 6).

\section{Interleukins and their receptors}

With the exception of the IL-4 receptor that is expressed at very low levels in some but not all undifferentiated ES cell samples, none of the interleukins or their receptors are expressed in undifferentiated ES cells (Fig. 6; Table 2 ). IL- $1 \alpha$ and IL-1 $\beta$, although functionally similar, are distinct unrelated genes and are induced at different time points during ES cell differentiation. IL- $1 \beta$ is expressed as early as day 12 , whereas IL- $1 \alpha$ cannot be detected before day 20. Although these two proteins are unrelated, they can bind to the same type I ("T cell") IL-1 receptor (Arai et al. 1990). The gene for this IL-1 receptor has its major transcriptional activation starting on day 12 .

IL- 4 and IL-6 have similar expression patterns, with both genes being expressed as early as day 2 and at the preculture stage, respectively (Fig. 6). Then both genes appear to be temporarily shut off, and no evidence for expression of either gene can be detected until day 12 . The IL-4 receptor is one of the earliest cytokine receptor genes to be expressed and is transcribed in significant amounts starting with the preculture stage. The murine IL- 6 receptor has not been cloned and could not be analyzed. IL-3 is an interleukin that is fundamentally involved with the in vitro development of hematopoietic colonies and was shown to act on primitive precursor cells (Iscove and Roitsch 1985; Suda et al. 1985; Bodine et al. 1989; Iscove and Yang 1990). Even after hybridization and prolonged exposure, no evidence of IL-3 expression was detected at any time during ES cell development nor was IL-3 message detected in normal lymphoid tissue (Fig. 6). However, IL-3 was easily detected in RNA from the WEHI-3 cell line in which it is constitutively expressed (Lee et al. 1982). Because of the sensitivity of our PCR reactions (see Materials and methods), we conclude that IL-3 is not expressed during ES cell differentiation. In contrast to the lack of expression of the cytokine, the IL-3 receptor was first detected as early as day 4 and continually increased its expression throughout the time course of the experiment (Fig. 6). A second gene was recently identified that is highly homologous to the IL-3 receptor but that does not bind IL-3 /Gorman et al. 1990). Although our PCR and hybridization primers do not distinguish between these two gene products, recent analysis with specific primers has indicated that the 


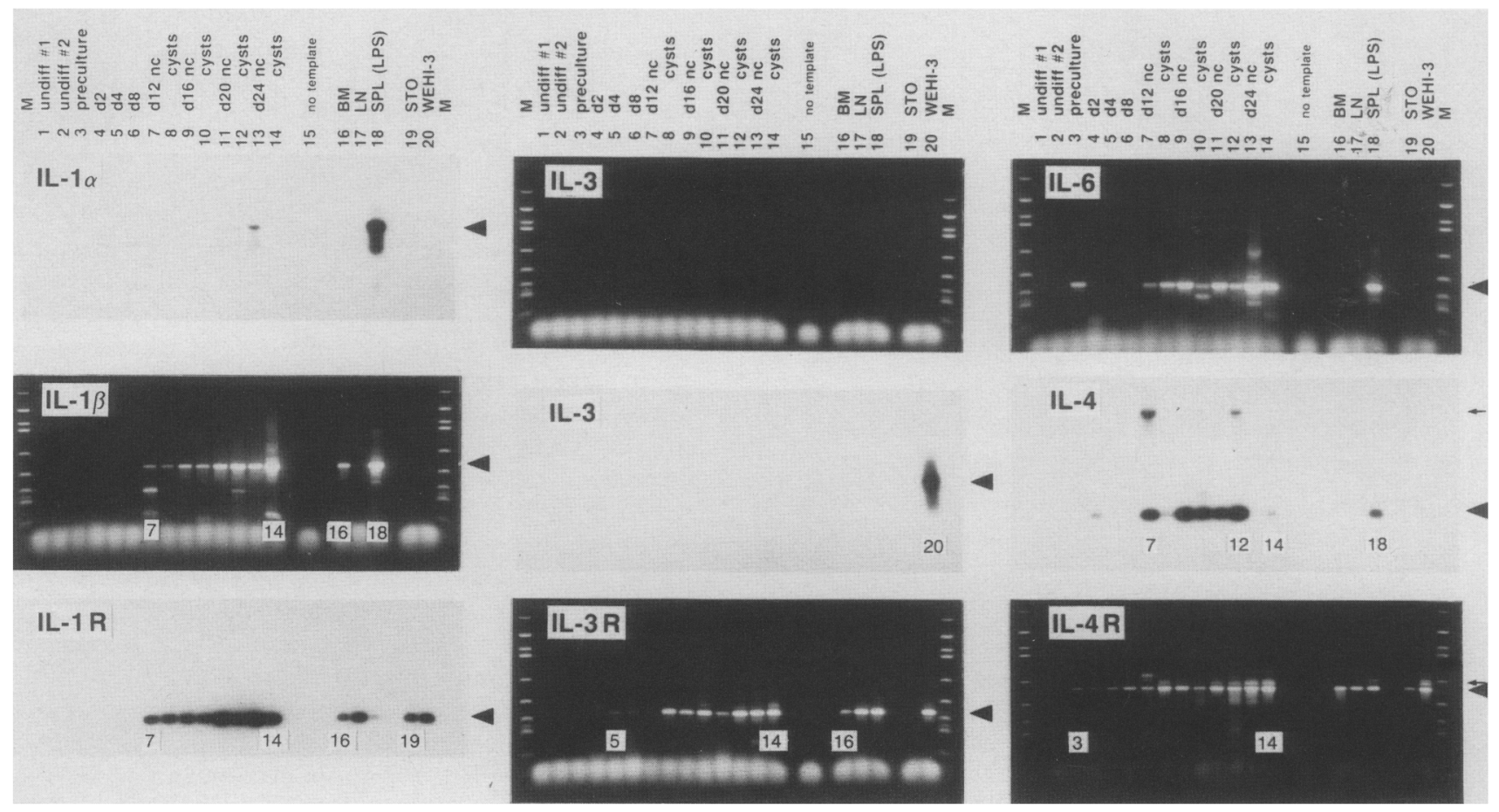

Figure 6. Expression of genes coding for interleukins and their receptors during ES cell differentiation analyzed by RT-PCR. Ethidium bromide stain or hybridization of the amplification products of: IL- $1 \alpha$, IL- $1 \beta$, IL-1 receptor, IL-3, IL-3 receptor, IL- 6 , IL-4, and IL-4 receptor. All amplifications were performed for 50 cycles with the exception of the IL-4 receptor, which was carried out for 40 cycles. The arrow indicates the genomic DNA band; the arrowhead indicates the cDNA band.

temporal expression of both genes is identical. The presence of functional IL-3 receptors is supported by the observation that exogenous IL-3 increases the frequency of myeloid CFU precursors that developed during ES cell differentiation (unpubl.).

\section{Expression of SLF and c-kit}

The SLF and its receptor are critical to hematopoietic development. Both genes are expressed throughout the time course even in undifferentiated ES cells (Fig. 7). c-kit is expressed relatively constantly, whereas $S 1$ undergoes a steady increase in expression up to day 24. Both of these genes are expressed at much higher levels than is seen in adult hematopoietic tissues.

\section{Discussion}

In this report we describe a novel in vitro model for studying hematopoietic development that is based on a culture system in which stable tissue culture clones of nonhematopoietic ES cells differentiate into mature hematopoietic cells. Our results clearly document the ability of nonhematopoietic ES cells to differentiate into most if not all of the hematopoietic colony-forming cells found in bone marrow. This conclusion is supported by the recent observations of Wiles and Keller (1991). There is a significant difference in the frequency of hematopoietic colonies derived from normal ES cells versus bone marrow. ES cells give rise to a higher percentage of mixed and erythroid (BFU-E) colonies but fewer pure monocytic and pure granulocytic colonies than normal bone marrow (see Results). On the basis of $\mathrm{CD} 45^{+}$subpopulation, differentiating ES cells produce 35 times more primitive precursors of mixed and erythroid colonies than normal bone marrow, approximately equal numbers of precursors for dual-lineage GM-CFUs, and nearly eightfold fewer precursors for single lineage myeloid CFUs. Approximately 1 of $100 \mathrm{CD}^{4} 5^{+}$hematopoietic cells that develop in these embryoid cysts is capable of forming in vitro colonies. The low number of pure monocytic and granulocytic colonies may represent a lack of appropriate cytokines, such as IL-3 (see below), to induce the differentiation and expansion of the more mature CFUs, or it may suggest that immature ES cell-derived hematopoietic precursors respond differently than adult cells to the factors in standard colony assays. It is interesting to compare these frequencies with that observed with fetal tissues. Although there is wide variation in the published results, day- 8 yolk sac cells produce a very high frequency, that of erythroid precursors similar to ES cell cultures, but on a per cell basis yolk sac cells produce more hematopoietic precursors than current ES cell cultures (Johnson and Barker 1985; Wong et al. 1986). The high frequency we observed within the hematopoietic cells of mixed CFUs that develop during ES cell differentiation is similar to that reported in the studies of yolk sac precursors by Johnson and Barker 


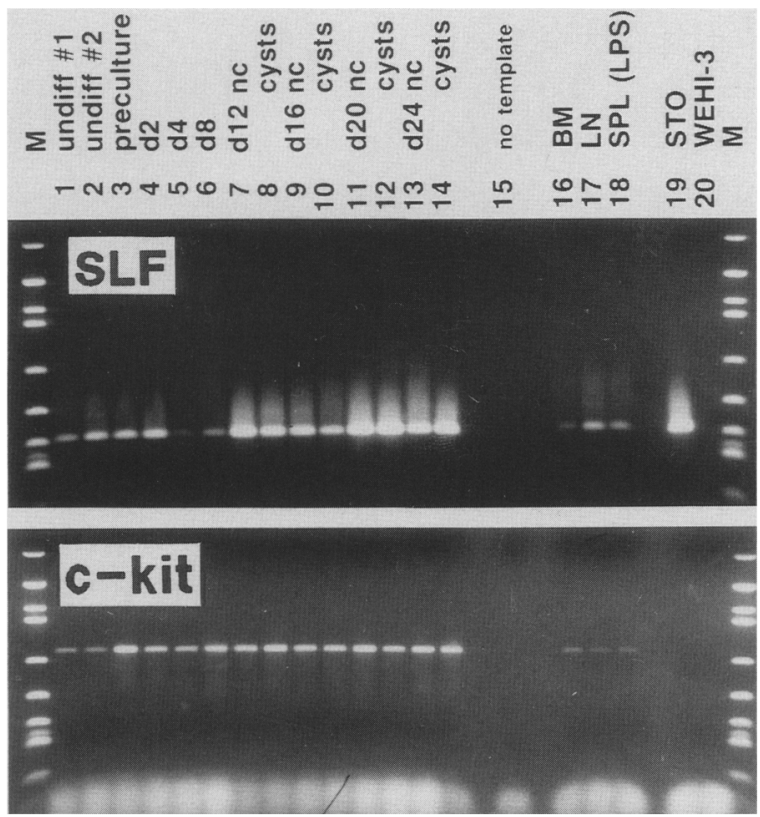

Figure 7. Expression of genes coding for c-kit (SLF) during ES cell differentiation analyzed by RT-PCR. Ethidium bromide stain of the amplification products of c-kit and SLF. Amplifications were performed for 35 cycles.

(1985) but is quantitatively different from the results of Wong et al. (1986). This altered frequency of precursors suggests that the CFUs that develop from ES cells are more immature than the majority of CFUs in bone marrow and indicates that the ES cell model more closely resembles, as would be predicted, fetal rather than adult hematopoietic development.

To better understand the extent of hematopoietic development that occurs in ES cell differentiation cultures, the expression of hematopoietic cell-specific surface markers was evaluated. None of these markers was expressed on undifferentiated ES cells (Table 1). CD45 (Ly5 ), a molecule that is expressed on most mature hematopoietic cells and colony-forming precursors, is expressed on $\sim 2 \%$ of the differentiated ES cells after day 16 (Table 1). The expression of B220, a splicing variant of CD45 that is specific for the B-cell lineage /Coffman and Weissman 1981), is detected on $0.3-0.5 \%$ of the cells. The significance of this small positive signal is not yet known, but this result may suggest that a low level of lymphoid differentiation is occurring in these cultures. The fact that the frequency of cells expressing granulocyte (RB6-8C5) (Coffman 1982) and macrophage (MAC-1) (Springer et al. 1978) markers was below the detection threshold of flow cytometry is consistent with the low number of myeloid CFUs obtained from these cultures. The low frequency of hematopoietic cells is documented further by the observations that two additional determinants that have been reported to be on immature precursors; that is, AA4.1 (McKearn et al. 1985; Jordan et al. 1990) and Ly-6 (LeClair et al. 1989; Shevach and Korty 1989; van de Rijn et al. 1989) are present on $<0.5 \%$ and $0.8 \%$ of these cells, respectively. This low frequency is to be expected because of the wide range of other cell types produced during ES cell differentiation.

As a first step toward understanding the molecular control of early hematopoietic development, we sought to correlate the expression of genes known to be important in hematopoiesis with the development of hematopoietic precursors that are produced during ES cell differentiation. Fetal $\beta$-globin is the predominant form expressed during the early stages of ES cell differentiation (preculture to day 8), whereas in methylcellulose cultures mature erythroid colonies switch and express almost exclusively the adult globin form (data not shown). The transcription of both globin genes increased dramatically by day 12 of differentiation, which corresponded to a steep rise in hematopoietic precursor development (Figs. 2 and 4). These changes in globin expression are similar to those obtained from yolk sac precursors (Wong et al. 1982, 1986) and those recently reported in ES cell cultures (Lindenbaum and Grosveld 1990; Wiles and Keller 1991) and demonstrate that the regulation of $\beta$-globin transcription in this in vitro system recapitulates the in vivo developmental regulation (Russell 1979).

Cytokines and their receptors play an important role in hematopoietic development. Of the genes that were analyzed, only $S l$ and c-kit were expressed at any significant level in undifferentiated ES cells, but most of the other cytokine and receptor genes underwent considerable transcriptional activation during ES cell differentiation before the major onset of hematopoietic precursor development. In most cases the receptor genes were transcribed before the corresponding growth factors (Table 2). It is informative that the growth factor receptors that are expressed on lineage-committed cells /GCSF and CSF-1 receptors) appear later than the IL-3 receptor and c-kit, which are expressed on less committed cells.

Epo and IL-6 have critical roles in hematopoietic differentiation. Recent data suggest that Epo also stimulates endothelial development (Anagnostou et al. 1990) and IL-6 may be involved in angiogenesis (Motro et al. 1990). This is directly relevant to the system described here because IL-6, Epo, and the Epo receptor genes show a very early onset of expression before hematopoietic development (Fig. 5), and the blood islands that form in the developing cysts are encased in endothelial structures (Doetschman et al. 1985). It may be that one of the early functions of Epo and IL-6 is to stimulate the development and activation of endothelial cells that are known to produce many cytokines (Nicola 1989). It is not known what cells within the differentiating ES cultures express Epo, but during fetal development Kupffer cells of the reticuloendothelial system in the fetal liver produce this growth factor (Gruber et al. 1977).

In addition to the factors produced de novo by differentiating ES cells, cytokines are also supplied by the HCS used as a media supplement. It is clear that HCS is supplying important factors because of its dramatic effects on the hematopoietic development of the ES cells, but it is unlikely that HCS is supplying GM-CSF, IL-3, 
IL-4, or SLF in a functional sense because of the species specificity of these factors (Lee et al. 1985; Mosmann et al. 1987; Otsuka et al. 1988; Martin et al. 1990). Therefore, if these factors are to play a role they must be produced de novo. The lack of transcription of the IL-3 and GM-CSF genes during the in vitro hematopoietic development of ES cells suggests that these two factors are not critical to this process. The role of IL-3 in normal hematopoiesis has been debated (Iscove and Roitsch 1985; Schrader et al. 1988; Whetton and Dexter 1988). Our conclusion that IL-3 does not have a role in the early stages of hematopoietic development lends support to the hypothesis that IL-3 is necessary only in times of hematopoietic crisis. SLF and its receptor (c-kit) have been reported to have IL-3-like activities on hematopoietic CFUs (Anderson et al. 1990; Martin et al. 1990), and it is possible that they may have a similar function during early hematopoietic development. The expression of c-kit and SI throughout ES cell differentiation (Fig. 7) and during embryonic development (Matsui et al. 1990; Orr-Urtreger et al. 1990) is consistent with this hypothesis. Also in this regard, the early expression of IL-6, IL-4, and the IL-4 receptor may be important (Fig. 6; Table 1). IL-6 enhances murine colony formation (Wong et al. 1988), and IL-6 in combination with IL-4 stimulates colony formation of various hematopoietic progenitor cells (Rennick et al. 1989). Thus, it is conceivable that the combination of IL-4 and IL- 6 has important synergistic effects on very primitive hematopoietic cells as well as having crucial roles, independent of hematopoiesis, early in fetal development (Murray et al. 1990).

In summary, we have demonstrated that differentiating ES cells produce most of the hematopoietic precursors that are found in bone marrow. During their in vitro development, ES cells express in a well-defined temporal order the genes for $\beta$-globin, cytokines and their receptors, and surface markers specific for hematopoietic cells. Our data suggest that IL-3 and GM-CSF are not critical to the early in vitro hematopoietic development and that the expression of SLF, Epo, IL-4, and IL- 6 may be important during the early stages of ES cell differentiation. This novel system makes it possible to study the control of growth and differentiation of mature hematopoietic cells from their nonhematopoietic precursors.

\section{Materials and methods}

ES cells

The isolation of the ES cell lines was basically performed as described (Robertson 1987). The 1E6/2 ES cell line, used throughout this report, was derived from a C57BL/6J-Gpi-1 ${ }^{\text {a }}$ mouse and maintained in Dulbecco's modified Eagle medium (DMEM), 20\% FCS, $150 \mu \mathrm{M} \alpha$-thioglycerol, $50 \mu \mathrm{g} / \mathrm{ml}$ of gentamicin, and $50 \%$ of 5637 supernatant as a source of LIF /Williams et al. 1988). The 1E6/2 line is karyotypically normal and male (data not shown). These cultures always contain a small percentage of differentiated ES cells; therefore, for the RNA analysis undifferentiated ES cells were obtained by picking colonies with micropipettes. To initiate differentiation, precultures were established by transferring $2 \times 10^{3}$ ES cells into new dishes with medium described above, and these were maintained for $6 \rightarrow 9$ days without further feeding. The large colonies formed during the preculture were harvested with dispase /Collaborative Research Laboratories|, washed, and transferred to bacterial dishes containing medium similar to that described above, except that $20 \%$ HCS was used in place of FCS and no LIF was added. The differentiation cultures were fed every 3 days by replacing half of the medium. Single-cell suspensions were prepared, from the entire cultures (days $0-8$ ) or separately from the macroscopically visible cysts and noncysts (days 12-28), by gentle mechanical agitation in PBS containing $0.25 \%$ trypsinEDTA (Sigma).

\section{In vitro colony assay}

Methylcellulose cultures were performed essentially as described (Iscove 1984) with FCS (4\%) and optimal concentrations of recombinant erythropoietin (Genetics Institute), IL-3 (Karasuyama and Melchers 1988), and 5637 supernatant as a source of IL-1 (Mochizuki et al. 1987). Colonies were counted after 8 and 12 days. Colony types were determined by morphology, and confirmed by cytological examination of May-GrünwaldGiemsa-stained colony smears.

\section{FACS analysis}

Standard two-stage immunofluorescence was performed using optimal concentrations of primary antibodies against CD45 (M1/9.3) (Springer et al. 1978), MAC-1 (M1/70.15.1) (Springer et al. 1978), B220 (14.8) (Kincade et al. 1981), RB6-8C5 (Coffman 1982), Thy- 1.2 (30-H12) (Ledbetter and Herzenberg 1979), Ly-6 (E13161-7) (Aihara et al. 1986), and AA4.1 (McKearn et al. 1984). The second stage was FITC-coupled $\mathrm{F}(\mathrm{ab})_{2}$ fragments of goatanti-rat immunoglobulin (Jackson Immunoresearch Laboratories). The cells were analyzed on a modified Coulter Epics V system. Negative controls were incubated with irrelevant isotype-matched controls and the second-stage antibody.

\section{RNA isolation and cDNA synthesis}

Total RNA was isolated by the acid phenol procedure (Chomczynski and Sacchi 1987). The first-strand cDNA reaction was performed using Moloney murine leukemia virus (Mo-MLV) reverse transcriptase (BRL) according to the manufacturer's protocol with 15 units of RNA guard and 20 pmoles of random hexamer primers (Pharmacia) in a $40-\mu$ l reaction. This reaction contained $\sim 20 \mathrm{ng}$ of total RNA, which represents approximately the equivalent of $2 \times 10^{3}$ cells. The same first-strand preparation was used for analyzing each of the genes. To control for template or other contaminations that would interfere with the PCR results, one first-strand reaction contained no RNA template (lane 15) and duplicates of each reaction were performed without reverse transcriptase (Figs. 3 and 4).

\section{PCR}

PCR amplifications (Saiki et al. 1988) were performed with $2.5 \%$ of the first-strand reaction product with Taq polymerase (2.5 units) (Promega) according to the manufacturer's protocol using 50 pmoles of each of the two gene-specific amplimers (Table 3) in a reaction volume of $100 \mu$ l. Most PCRs were assayed at two different cycle numbers by removing one-half of the reaction volume at appropriate times during the amplification. This allowed for the control of "saturation effects" of the PCR, which made it possible to better judge quantitative differences between samples. The reactions were carried out in a 
Table 3. Oligonucleotide primers for studying gene expression during in vitro differentiation of ES cells

\begin{tabular}{|c|c|c|c|}
\hline Gene & $5^{\prime}$ & lers & $\begin{array}{l}\text { Size } \\
(b p)^{a}\end{array}$ \\
\hline IL-1 $\alpha$ & AAGGAGAGCCGGGTGACAGTAT & GATGCCTGTCAAGCTCAGAGGA & 1270 \\
\hline IL-1 $\beta$ & TAGGCTCA TCTGGGATCCTCTC & TACCAGTTGGGGAACTCTGCAG & 770 \\
\hline IL-1 receptor & CTGTTGGTGAGGAATGTGGCTG & AGCCGTGAGGATGATAAAGCCC & 501 \\
\hline IL-3 & TTCTTGCCAGCTCTACCACCAG & ACTTTAGGTGCTCTGCCTGCTG & 522 \\
\hline IL-3 receptor & TTCCTTTGGGCTCTTCTATCGC & CCAGGAGCAAGGTGAAGATGAG & 554 \\
\hline IL-4 & TCTGTAGGGCTTCCAAGGTGCT & GATGCTCTTTAGGCTTTCCAGG & 191 \\
\hline IL-4 receptor & CTGTGGGCTGTCTGATTTTGCT & TCCTGGCT TCGGGTCTGCTTAT & 856 \\
\hline IL-6 & AACCACGGCCTTCCCTACT TCA & GCATAACGCACTAGGTTTGCCG & 585 \\
\hline CSF-1 & GTCAGAACACTGTAGCCACATG & CTGTCAACGGCCTGTCTGTTAT & 993 \\
\hline CSF-1 receptor & GCGATGTGTGAGCAATGGCAGT & AGACCGTTTTGCGTAAGACCTG & 341 \\
\hline G-CSF & CCAACTTTGCCACCACCATCTG & GGAGCAGCAGCAGGAATCAATA & 427 \\
\hline G-CSF receptor & ССССТСАААССТАТССТGССТС & TCCAGGCAGAGATGAGCGAATG & 567 \\
\hline GM-CSF & TGAGGAGGA TGTGGCTGCAGAA & TGTGCCACATCTCTTGGTCCCT & 544 \\
\hline Epo & ACGTCCCACCCTGCTGCTTTTA & CGTGTACAGCTTCAGTTTCCCC & 532 \\
\hline Epo receptor & TTCTCCTCGCTATCACCGCATC & ССТСAAACTCGСТСTCTGGGCT & 497 \\
\hline c-kit & CAACAGCAATGGCCTCACGAGT & GTGGTACACCTTTGCTCTGCTC & 1069 \\
\hline SLF & CGCTGCCTTTCCTTATGAAGAAGA & CGGGACCTAATGTTGAAGAGAGCA & 528 \\
\hline CD45 (Ly-5) & ССТGAGTCTGCATCTAAACCCC & TGCTTGGCCAGTATTCTGCGCA & 1067 \\
\hline Thy-1 & ACAGCCTGCCTGGTGAACCAAA & GGCCCAACCAGTCACAGAGAAA & 423 \\
\hline$\beta$-Globin $(y)$ (fetal) & AACCCTCATCAATGGCCTGTGG & TCAGTGGTACTTGTGGGACAGC & 415 \\
\hline$\beta$-Globin (bl) (adult) & ATGGTGCACCTGACTGATGCTG & GGTTTAGTGGTACTTGTGAGCC & 444 \\
\hline$\beta$-Actin & GTGACGAGGCCCAGAGCAAGAG & AGGGGCCGGACTCATCGTACTC & 934 \\
\hline
\end{tabular}

${ }^{a}$ Size of the amplified cDNA product in base pairs.

Cetus thermocycler for $25-50$ cycles consisting of $1^{\prime} 94^{\circ} \mathrm{C}, 1^{\prime}$ $60-65^{\circ} \mathrm{C}$ /depending on the melting temperature of the primer pair), $2^{\prime} 72^{\circ} \mathrm{C}$ with $2^{\prime \prime}$ increments per cycle. The specificity of the PCR product was established by comparing the size of the amplified product to the expected cDNA band, and most were hybridized with an internal oligonucleotide. As an internal standard, all cDNA samples were adjusted to yield relatively equal amplification of $\beta$-actin (Fig. 3). Densitometric analysis of the $\beta$-actin amplification revealed that the samples had a coefficient of variance of 0.34 (data not shown) that was insignificant compared with the changes in message levels observed during differentiation for the other genes. Figure 4 shows the reverse transcriptase-negative control, a control performed in all PCR experiments, for the globin genes, which amplifies contaminating DNA (genomic or otherwise) in the RNA preparation. The sensitivity of our PCR reaction was estimated by titrating a known number of synthetic RNA molecules with the relevant primer sites into a first-strand reaction with RNA known to be negative for the message of interest (Wang et al. 1989). This technique controls for the efficiency of the firststrand synthesis as well as the amplification efficiency of the specific primer pairs used. These experiments indicate that by ethidium bromide-stained gels we can reproducibly detect IL-3 or GM-CSF by analyzing one-third of our standard PCR reaction in which the cDNA derived from 10-100 RNA molecules was amplified (data not shown). This sensitivity is generally increased by at least a factor of 10 by hybridization with 12 - to 48-hr exposure times. There was no detectable expression of IL-3 or GM-CSF in differentiating ES cultures even after 12-14 days of exposures.

\section{Analysis of PCR products}

An aliquot of each PCR reaction was separated on agarose gels, and the DNA was blotted with $0.4 \mathrm{~N} \mathrm{NaOH}$ onto Zeta probe membranes (Bio-Rad). The blots were hybridized with internal oligonucleotides, unrelated to the PCR primers, specific for the respective amplification product, and washed at a final stringency of $20 \mathrm{~mm}$ Tris- $\mathrm{HCl}(\mathrm{pH} 8), 100 \mathrm{~mm} \mathrm{NaCl}, 0.6 \mathrm{~mm}$ EDTA, and $0.1 \%$ SDS at $2-5^{\circ} \mathrm{C}$ below the melting temperature of the probe.

\section{Acknowledgments}

We thank Dr. John Baskar for his help in isolating the mouse blastocysts used for establishing our ES cell lines; Dr. John Wiley for performing the karyotypic analysis; Dr. Dennis Ross for assisting us in analyzing the hematopoietic colony smears; Drs. Norman Iscove, Gordon Keller, and Edison Liu for critically reading the manuscript; Judy Smith for running the FACS equipment; and all of the nurses of the Labor and Delivery Ward of UNC Memorial Hospital for helping us collect the HCS. This work has been supported in part by grant IN-15-31 from the American Cancer Society, by an Academic Research Initiation Grant from the North Carolina Biotechnology Center, and by Developmental Funds from the Lineberger Comprehensive Cancer Center.

The publication costs of this article were defrayed in part by payment of page charges. This article must therefore be hereby marked "advertisement" in accordance with 18 USC section 1734 solely to indicate this fact.

\section{References}

Abramson, S., R.G. Miller, and R.A. Phillips. 1977. The identification in adult bone marrow of pluripotent and restricted stem cells of the myeloid and lymphoid systems. J. Exp. Med. 145: 567-1579.

Aihara, Y, H.-J. Bühring, M. Aihara, and J. Klein. 1986. An attempt to produce "pre- $T$ " cell hybridomas and to identify their antigens. Eur. J. Immunol. 16: 1391-1399.

Anagnostou, A., E.S. Lee, N. Kessimian, R. Levinson, and M. 
Steiner. 1990. Erythropoietin has a mitogenic and positive chemotactic effect on endothelial cells. Proc. Natl. Acad. Sci. 87: 5978-5982.

Anderson, D.M., S.D. Lyman, A. Baird, J.M. Wignall, J. Eisenman, C. Rauch, C.J. March, H.S. Boswell, S.D. Gimpel, D. Cosman, and D.E. Williams. 1990. Molecular cloning of mast cell growth factor, a hematopoietin that is active in both membrane bound and soluble forms. Cell 63: 235-243.

Arai, K.-I., F.L. Lee, A. Miyajima, S. Miyatake, N. Arai, and T. Yokota. 1990. Cytokines: Coordinators of immune and inflammatory responses. Annu. Rev. Biochem. 59: 783-836.

Berman, J.W. and R.S. Basch. 1985. Thy-1 antigen expression by murine hematopoietic precursor cells. Exp. Hematol. 13: $1152-1156$.

Bodine, D.M., S. Karlsson, and A.W. Nienhuis. 1989. Combination of interleukin 3 and 6 preserves stem cell function in culture and enhances retrovirus-mediated gene transfer into hematopoietic stem cells. Proc. Natl. Acad. Sci. 86: 88978901.

Bradley, A., M. Evans, M.H. Kaufman, and E. Robertson. 1984. Formation of germ-line chimaeras from embryo-derived teratocarcinoma cell lines. Nature 309: 255-256.

Chabot, B., D.A. Stephenson, V.M. Chapman, P. Besmer, and A. Bernstein. 1988. The proto-oncogene c-kit encoding a transmembrane tyrosine kinase receptor maps to the mouse $W$ locus. Nature 335: 88-89.

Chomczynski, P. and N. Sacchi. 1987. Single-step method of RNA isolation by acid guanidinium thiocyanate-phenolchloroform extraction. Anal. Biochem. 162: 156-159.

Coffman, R.L. 1982. Surface antigen expression and immunoglobulin gene rearrangement during mouse pre-B cell development. Immunol. Rev. 69: 5-23.

Coffman, R.L. and I.L. Weissman. 1981. B220: A B cell specific marker of the T200 glycoprotein family. Nature 289: 681683.

Doetschman, T.C., H. Eistetter, M. Katz, W. Schmidt, and R. Kemler. 1985. The in vitro development of blastocyst-derived embryonic stem cell lines: Formation of visceral yolk sac, blood islands and myocardium. I. Embryol. Exp. Morph. 87: 27-45.

Evans, M.J. and M.H. Kaufman. 1981. Establishment in culture of pluripotent cells from mouse embryos. Nature 292: 154 156.

Geissler, E.N., M.A. Ryan, and D.E. Housman. 1988. The dominant-white spotting $(W)$ locus of the mouse encodes the c-kit proto-oncogene. Cell 55: 185-192.

Gorman, D.M., N. Itoh, T. Kitamura, J. Schreurs, S. Yonehara, I. Yahara, K.-I. Arai, and A. Miyajima. 1990. Cloning and expression of a gene encoding an interleukin 3 receptor-like protein: Identification of another member of the cytokine receptor gene family. Proc. Nat1. Acad. Sci. 87: 5459-5463.

Gruber, D.F., J.R. Zucali, and E.A. Mirand. 1977. Identification of erythropoietin producing cells in fetal mouse liver cultures. Exp. Hematol. 5: 392-398.

Iscove, N.N. 1984. Culture of lymphocytes and hematopoietic cells in serum-free medium. In Methods for serum-free culture of neuronal and lymphoid cells (ed. D. Barnes, D. Sirbascu, and G. Satol, pp. 169-185. Alan R. Liss, New York.

Iscove, N.N. and C. Roitsch. 1985. The multilineage hematopoietic growth factors. In Cellular and molecular biology of lymphokines (ed. A. Schimple and C. Sorg), pp. 397424. Academic Press, New York.

Iscove, N.N. and F. Sieber. 1975. Erythroid progenitors in mouse bone marrow detected by macroscopic colony formation in culture. Exp. Hematol. 3: 32-43.

Iscove, N.N. and Y.Q. Yang. 1990. Precursors (pre-CFU multi ) of multilineage hemopoietic colony-forming cells quantitated in vitro. Uniqueness of IL-1 requirement, partial separation from pluripotential colony forming cells and correlation with long term reconstituting cells in vivo. I. Immunol. 145: $190-195$.

Johnson, G.R. and D.C. Barker. 1985. Erythroid progenitor cells and stimulating factors during murine embryonic and fetal development. Exp. Hematol. 13: 200-208.

Jordan, C.T., J.P. McKearn, and I.R. Lemischka. 1990. Cellular and developmental properties of fetal hematopoietic stem cells. Cell 61: 953-963.

Karasuyama, H. and F. Melchers. 1988. Establishment of mouse cell lines which constitutively secrete large quantities of interleukin 2, 3, 4, or 5 using modified cDNA expression vectors. Eur. I. Immunol. 18: 97-104.

Kincade, P.W., G. Lee, T. Watanabe, L. Sun, and M.P. Scheid. 1981. Antigens displayed on murine B lymphocyte precursors. J. Immunol. 127: 2262-2268.

LeClair, K.P., M.M. Bridgett, F.J. Dumont, R.G. Palfree, U. Hammerling, and A.L. Bothwell. 1989. Kinetic analysis of Ly- 6 gene induction in a T lymphoma by interferons and interleukin 1 and demonstration of Ly-6 inducibility in diverse cell types. Eur. J. Immunol. 19: 1233-1239.

Ledbetter, J.A. and L.A. Herzenberg. 1979. Xenogenic monoclonal antibodies to mouse lymphoid differentiation antigens. Immunol. Rev. 47: 63-90.

Lee, J.C., A.J. Hapel, and J.N. Ihle. 1982. Constitutive production of a unique lymphokine (IL-3) by the WEHI-3 cell line. I. Immunol. 128: 2393-2397.

Lee, F., T. Yokota, T. Otsuka, L. Gemmell, N. Larson, J. Luh, K. Arai, and D. Rennick. 1985. Isolation of cDNA for a human granulocyte-macrophage colony-stimulating factor by functional expression in mammalian cells. Proc. Natl. Acad. Sci. 82: $4360-4364$.

Lindenbaum, M.H. and F. Grosveld. 1990. An in vitro globin gene switching model based on differentiated embryonic stem cells. Genes \& Dev. 4: 2075-2085.

Martin, G. 1981. Isolation of a pluripotent cell line from early mouse embryos cultured in medium conditioned by teratocarcinoma stem cells. Proc. Natl. Acad. Sci. 78: 7634-7638.

Martin, G. and M.J. Evans. 1975a. Differentiation of clonal lines of teratocarcinoma cells: Formation of embryoid bodies in vitro. Proc. Natl. Acad. Sci. 72: 1441-1445.

- 1975b. The formation of embryoid bodies in vitro by homogeneous embryonal carcinoma cell cultures derived from isolated single cells. In Teratomas and differentiation (ed. M.I. Sherman and D. Solter), pp. 169. Academic Press, New York.

Martin, F.H., S.V. Suggs, K.E. Langley, H.S. Lu, J. Ting, K.H. Okino, C.F. Morris, I.K. McNiece, F.W. Jacobsen, E.A. Mendiaz, N.C. Birkett, K.A. Smith, M.J. Johnson, V.P. Parker, J.C. Flores, A.C. Patel, E.F. Fisher, H.O. Erjavec, C.J. Herrera, J. Wypych, R.K. Sachdev, J.A. Pope, I. Leslie, D. Wen, C.-H. Lin, R.L. Cupples, and K.M. Zsebo. 1990. Primary structure and functional expression of rat and human stem cell factor DNAs. Cell 3: 203-211.

Matsui, Y., K.M. Zsebo, and B.L.M. Hogan. 1990. Embryonic expression of a haematopoietic growth factor encoded by the S1 locus and the ligand for c-kit. Nature 347: 667-669.

McKearn, J.P., C. Baum, and J.M. Davie. 1984. Cell surface antigens expressed by a subset of pre-B cells and B cells. I. Immunol. 132: 332-339.

McKearn, J.P., J. McCubrey, and B. Fagg. 1985. Enrichment of hematopoietic precursor cells and cloning of multipotential B-lymphocyte precursors. Proc. Natl. Acad. Sci. 82: 74147418 . 
Metcalf, D., G.R. Johnson, and A.W. Burgess. 1980. Direct stimulation by purified GM-CSF of the proliferation of multipotential and erythroid precursor cells. Blood 55: 138-147.

Micklem, H.S. and D.A. Ogden. 1976. Ageing of haematopoietic stem cell populations in the mouse. In Stem cells of renewing cell populations. (ed. A.B. Cairnie, P.K. Lala, and D.G. Osmond), pp. 331-341. Academic Press, New York,

Miller, B.A., G. Antognetti, and T.A. Springer. 1985. Identification of cell surface antigens present on murine hematopoietic stem cells. J. Immunol. 134: 3286-3290.

Mochizuki, D.Y., J.R. Eisenman, P.J. Conlon, A.D. Larsen, and R.J. Tushinski. 1987. Interleukin 1 regulates hematopoietic activity, a role previously ascribed to hemopoietin 1. Proc. Natl. Acad. Sci. 84: 5267-5271.

Mosmann, T.R., T. Yokota, R. Kastelein, S.M. Zurawski, N. Arai, and Y. Takebe. 1987. Species-specificity of T cell stimulating activities of IL 2 and BSF-1 (IL 4): Comparison of normal and recombinant, mouse and human IL 2 and BSF-1 (IL-4). J. Immunol. 138: 1813-1816.

Motro, B., A. Itin, L. Sachs, and E. Keshet. 1990. Pattern of interleukin 6 gene expression in vivo suggests a role for this cytokine in angiogenesis. Proc. Natl. Acad. Sci. 87: 30923096.

Murray, R., F. Lee, and C.P. Chiu. 1990. The genes for leukemia inhibitory factor and interleukin- 6 are expressed in mouse blastocysts prior to the onset of hemopoiesis. Mol. Cell. Biol. 10: 4953-4956.

Nicola, N.A. 1989. Hematopoietic cell growth factors and their receptors. Annu. Rev. Biochem. 58: 45-77.

Nicola, N.A., D. Metcalf, M. Matsumota, and G.R. Johnson. 1983. Purification of a factor inducing differentiation in $\mathrm{mu}$ rine myelomonocytic leukemia cells: Identification as granulocyte colony-stimulating factor (G-CSF). I. Biol. Chem. 258: 9017-9023.

Ohara, O., R.L. Dorit, and W. Gilbert. 1989. One-sided polymerase chain reaction: The amplification of cDNA. Proc. Natl. Acad. Sci. 86: 5673-5677.

Orr-Urtreger, A., A. Avivi, Y. Zimmer, D. Givol, Y. Yarden, and P. Lonai. 1990. Developmental expression of c-kit, a protooncogene encoded by the $W$ locus. Development 109: $911-$ 923.

Otsuka, T., A. Miyajima, N. Brown, K. Otsu, J. Abrams, S. Saeland, C. Caux, R.D. Waal Malefijt, J. De Vries, P. Meyerson, K. Yokota, L. Gemmel, D. Rennick, F. Lee, N. Arai, K.-I. Arai, and T. Yokota. 1988. Isolation and characterization of an expressible cDNA encoding human IL-3. Induction of IL-3 mRNA in human $\mathrm{T}$ cell clones. I. Immunol. 140: 22882295.

Paul, W.E. and J. Ohara. 1987. B-cell stimulatory factor-1/interleukin-4. Annu. Rev. Immunol. 5: 429-459.

Reif, A.E. and J.M.V. Allen. 1964. The AKR thymic antigen and its distribution in leukemias and nervous tissues. J. Exp. Med. 120: 413-433.

Rennick, D., J. Jackson, G. Yang, J. Wideman, F. Lee, and S. Hudak. 1989. Interleukin-6 interacts with interleukin-4 and other hematopoietic growth factors to selectively enhance the growth of megakaryocytes, erythroid, myeloid and multipotential progenitors cells. Blood 73: 1828-1835.

Robertson, E.J. 1987. Embryo-derived stem cell lines. In Teratocarcinomas and embryonic stem cells: $A$ practical approach (ed. E.J. Robertson), pp. 71-112. IRL Press, Oxford.

Russell, E.S. 1979. Hereditary anemias of the mouse: A review for geneticists. Adv. Gen. 20: 357-459.

Saiki, R.K., D.H. Gelfand, S. Stoffel, S.J. Scharf, R. Higuchi, G.T. Horn, K.B. Mullis, and H.A. Erlich. 1988. Primer-directed enzymatic amplification of DNA with a thermostable DNA polymerase. Science 239: 487-491.

Schrader, I.W., I. Clark-Lewis, R.M. Crapper, K.B. Leslie, S. Schrader, G. Varigos, and H.J. Ziltener. 1988. The panspecific hemopoietin interleukin 3: Physiology and pathology. Lymphokines 15: 281-311.

Shevach, E.M. and P.E. Korty. 1989. Ly-6: A multigene family in search of a function. Immunology Today 10: 195-200.

Silvers, W.K. 1979. Dominant spotting, patch, and rump-white. In The coat colors of mice: A model for mammalian gene action and interaction. pp. 208-232. Springer-Verlag, New York.

Springer, T.A., G. Galfre, D.S. Secher, and C. Milstein. 1978. Monoclonal xenogenic antibodies to murine cell surface antigens: Identification of novel leukocyte differentiation antigens. Eur. I. Immunol. 8: 539-551.

Stanley, E.R. and P.M. Heard. 1977. Factors regulating macrophage production and growth. Purification and some properties of the colony stimulating factor. 1 . Biol. Chem. 252: 4305-4312.

Suda, T., J. Suda, M. Ogawa, and J.N. Ihle. 1985. Permissive role of interleukin 3 in proliferation and differentiation of multipotential hematopoietic progenitors in culture. J. Cell. Physiol. 124: 182-188.

Suda, Y., M. Suzuki, Y. Ikawa, and S. Aizawa. 1987. Mouse embryonic stem cells exhibit indefinite proliferative potential. J. Cell. Physiol. 133: 197-201.

Thomas, M.L. 1989. The leukocyte common antigen family. Ann. Rev. Immunol. 7: 339-369.

van de Rijn, M., S. Heimfeld, G.J. Spangrude, and I.L. Weissman. 1989. Mouse hematopoietic stem-cell antigen Sca-1 is a member of the Ly-6 antigen family. Proc. Natl. Acad. Sci. 86: 4634-4638.

Wang, A.M., M.V. Doyle, and D.F. Mark. 1989. Quantitation of mRNA by the polymerase chain reaction. Proc. Natl. Acad. Sci. 86: 9717-9721.

Whetton, A.D. and T.M. Dexter. 1988. The mode of action of interleukin 3 in promoting survival, proliferation, and differentiation of hemopoietic progenitor cells. Lymphokines 15: 355-374.

Wiles, M.V. and G. Keller. 1991. Multiple hematopoietic lineages develop from embryonic stem (ES) cells in culture. Development (in press).

Williams, R.L., D.J. Hilton, S. Pease, T.A. Wilson, C.L. Stewart, D.P. Gearing, E.F. Wagner, D. Metcalf, N.A. Nicola, and N.M. Gough. 1988. Myeloid leukemia inhibitory factor maintains the developmental potential of embryonic stem cells. Nature 336: 684-687.

Wong, P.M.C., G.J. Clarke, D.H. Carr \& D.H.K. Chui. 1982. Adult hemoglobins are synthesized in erythroid colonies in vitro derived from murine circulating hematopoietic progenitor cells during embryonic development. Proc. Nat1. Acad. Sci. 79: 2952-2956.

Wong, P.M.C., S.W. Chung, D.H.K. Chui, and C.J. Eaves. 1986. Properties of the earliest clonogenic hematopoietic precursors to appear in the developing murine yolk sac. Proc. Natl. Acad. Sci. 83: 3851-3854.

Wong, G.G., J.S. Witek-Giannotti, P.A. Temple, R. Kriz, C. Ferenz, R.M. Hewick, S.C. Clark, K. Ikebuchi, and M. Ogawa. 1988. Stimulation of murine hematopoietic colony formation by human IL-6. J. Immunol. 140: 3040-3044.

Zsebo, K.M., J. Wypych, I.K. McNeice, H.S. Lu, K.A. Smith, S.B. Karkare, R.K. Sachdev, V.N. Yuschenkoff, N.C. Birkett, L.R Williams, V.N. Satyagal, W. Tung, R.A. Bosselman, E.A. Mendiaz, and K.E. Langley. 1990. Identification, purification and biological characterization of hematopoietic stem cell factor from buffalo rat liver-conditioned medium. Cell 63: 195-201. 


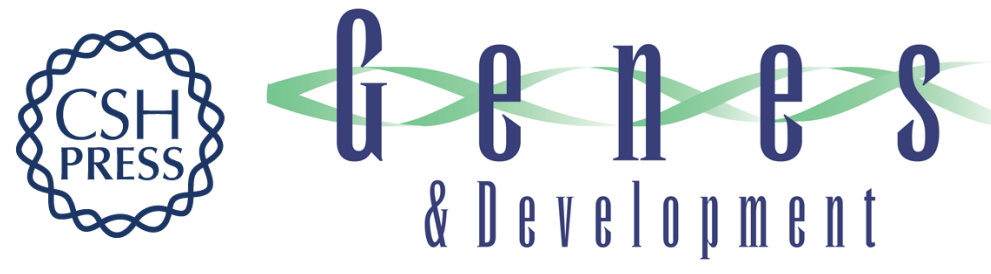

\section{Hematopoietic development of embryonic stem cells in vitro: cytokine and receptor gene expression.}

R M Schmitt, E Bruyns and H R Snodgrass

Genes Dev. 1991, 5:

Access the most recent version at doi:10.1101/gad.5.5.728

References This article cites 65 articles, 31 of which can be accessed free at:

http://genesdev.cshlp.org/content/5/5/728.full.html\#ref-list-1

License

Email Alerting

Service

Receive free email alerts when new articles cite this article - sign up in the box at the top right corner of the article or click here.

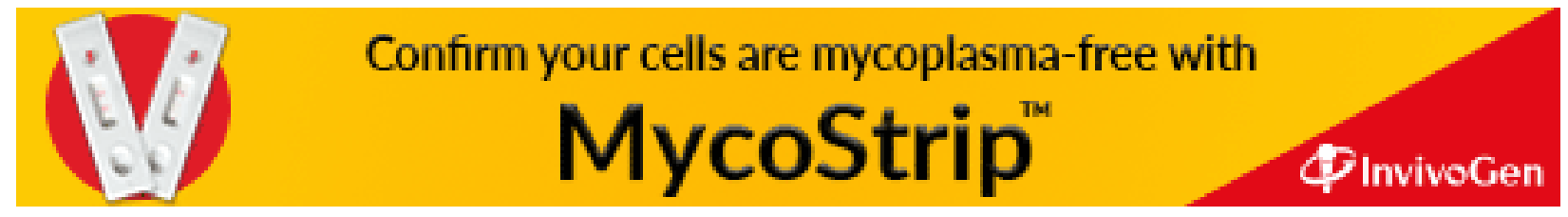

